\title{
Instrumental Genesis of a Learning Trajectory: The Case of Pedro's Professional Noticing
}

\author{
Gloria Sánchez-Matamoros (1Da \\ Mar Moreno Moreno ${ }^{\mathrm{b}}$ \\ Julia Valls González $\mathbb{D}^{\mathrm{b}}$ \\ ${ }^{\text {a } U n i v e r s i d a d ~ d e ~ S e v i l l a, ~ F a c u l t a d ~ d e ~ C i e n c i a s ~ d e ~ l a ~ E d u c a c i o ́ n, ~ D e p a r t a m e n t o ~ d e ~ D i d a ́ c t i c a ~ d e ~ l a s ~}$ \\ Matemáticas, Sevilla, Spain \\ ${ }^{\mathrm{b}}$ Universidad de Alicante, Facultad de Educación, Departamento de Innovación y Formación Didáctica, \\ San Vicente del Raspeig, Alicante, Spain
}

Received for publication 30 Nov. 2020. Accepted after review 29 Jul. 2021.

Designated editor: M. Mar Liñán García

\begin{abstract}
Background: Many teacher education programmes aim for prospective teachers to learn to notice mathematics teaching-learning situations based on learning trajectories of specific concepts. However, there has not been a deeper study on how they use that knowledge to notice children's mathematical thinking. Objective: To identify characteristics of the instrumental genesis process in an early childhood prospective teacher as he notices a classroom situation using a learning trajectory of length and its measurement as an artefact. Design: We have adapted Rabardel's instrumental approach. Settings and Participants: An early childhood prospective teacher solving a professional task (case study). Data collection and analysis: We analyse the student's activity while solving the task, considering the processes of instrumental genesis. Results: The outcomes reveal characteristics of professional noticing skills: (a) providing mathematical meaning to the elements allows constructing utilisation schemes to identify; (b) considering the inclusiveness of levels of understanding and the continuity of progression in learning allows constructing utilisation schemes to interpret, and (c) considering the sequentiality of levels of understanding allows constructing utilisation schemes to make decisions. Conclusions: Instrumental genesis allows identifying which schemes a kindergarten prospective teacher constructs and how he/she acquires his/her professional noticing, and provides information for the teacher educator to make instructional decisions. For example, in our case, the teacher educator provides the prospective teacher of this case study with tasks to give meaning to the transitivity element and variety of contexts related to conservation.
\end{abstract}

Keywords: Instrumental genesis; Learning trajectory; Professional Noticing; Length and its measurement; Early childhood education.

Corresponding author: Gloria Sánchez-Matamoros García. Email: gsannchezmatamoros@us.es 


\section{Génesis instrumental de una trayectoria de aprendizaje: el caso de la mirada profesional de Pedro}

\section{RESUMEN}

Contexto: Muchos programas de formación docente pretenden que los futuros profesores aprendan a mirar situaciones de enseñanza-aprendizaje de matemáticas apoyándose en trayectorias de aprendizaje de conceptos específicos. Sin embargo, no se ha profundizado en cómo usan el conocimiento de éstas para mirar el pensamiento matemático de los niños. Objetivo: identificar características del proceso de génesis instrumental en un estudiante para maestro de Educación Infantil cuando mira una situación de aula usando una trayectoria de aprendizaje de longitud y su medida como artefacto. Diseño: hemos adaptado el enfoque instrumental de Rabardel. Escenario y Participante: un estudiante para maestro resolviendo una tarea profesional (estudio de caso). Recogida y análisis de datos: se analiza la actividad del estudiante resolviendo la tarea considerando los procesos de la génesis instrumental. Resultados: proporcionan características de las destrezas de la mirada profesional: (a) dotar de significado matemático a los elementos permite construir esquemas de utilización para identificar; (b) considerar la inclusividad de los niveles de comprensión y la continuidad de la progresión en el aprendizaje permite construir esquemas de utilización para interpretar, y (c) considerar la secuencialidad de los niveles de comprensión permite construir esquemas de utilización para tomar decisiones. Conclusiones: la génesis instrumental permite identificar qué esquemas construye el estudiante para maestro y cómo adquiere su mirada profesional, y proporciona información al formador de profesores para tomar decisiones instruccionales. Por ejemplo, para el estudiante de este caso, el formador proporcionará tareas para dotar de significado al elemento transitividad y variedad de contextos relacionados con la conservación.

Palabras clave: génesis instrumental; trayectoria de aprendizaje; mirada profesional; longitud y su medida; educación infantil.

\section{Gênese instrumental de uma trajetória de aprendizagem: o caso do olhar professional de Pedro}

\section{RESUMO}

Contexto: Muitos programas de formação de professores têm como objetivo que os futuros professores aprendam a olhar para as situações de ensino-aprendizagem da matemática a partir de trajetórias de aprendizagem de conceitos específicos. No entanto, não se aprofundaram em conhecer como eles usam seu conhecimento para olhar para o pensamento matemático das crianças. Objetivo: Identificar características do processo de gênese instrumental em um futuro professor de educação infantil ao 
olhar para uma situação de sala de aula a partir de uma trajetória de aprendizagem de comprimento e sua medição como artefato. Design: Adaptamos a abordagem instrumental de Rabardel. Cenário e participante: Um futuro professor resolvendo uma tarefa profissional (estudo de caso). Coleta e análise de dados: Analisa-se a atividade do aluno ao resolver a tarefa, considerando os processos de gênese instrumental. Resultados: Fornecem características das habilidades do olhar profissional: (a) dotar os elementos de significado matemático permite construir esquemas de utilização para identificar; (b) considerar a inclusividade dos níveis de compreensão e a continuidade da progressão na aprendizagem permite a construção de esquemas de utilização para interpretar, e (c) considerar a sequencialidade dos níveis de compreensão permite a construção de esquemas de utilização para tomar decisões. Conclusões: A gênese instrumental permite identificar quais esquemas o futuro professor constrói e como adquire seu olhar profissional, além de fornecer informações ao formador para a tomada de decisões instrucionais. Por exemplo, para o futuro professor, neste caso, o formador fornecerá tarefas para dar sentido ao elemento de transitividade e variedade de contextos relacionados à conservação.

Palavras-chave: gênese instrumental; trajetória de aprendizagem; olhar profissional; comprimento e sua medição; educação infantil.

\section{INTRODUCTION}

Many current teacher education programmes design their teaching modules aiming to help prospective teachers learn how to notice at mathematics teaching-learning situations (Bartell et al., 2013; Llinares, 2012; Stokero, 2014; Wilson et al., 2013). Although there are different conceptions about professional noticing (Mason, 2002; Sherin \& van Es, 2009), they all focus on interpreting classroom situations to make teaching-learning decisions.

Research works on professional development have focused mainly on the level of primary education (Krupa et al., 2017), with fewer focusing on early childhood education (Parks \& Wager, 2015). Recent rstudies consider that early childhood teachers must develop skills to recognise everyday situations and turn them into teaching-learning situations (Gasteiger \& Benz, 2018; Gasteiger et al., 2020). These types of situations of exploring and recognising the concept should allow children to transform informal mathematical knowledge into formal mathematical knowledge (Empson \& Junk 2004). For this, early childhood education teachers must have specific knowledge to interpret mathematical situations and favour progression in children's learning (Lee, 2017).

Currently, studies that focuses on characterising and favouring the development of professional noticing (Amador, 2020; Fernández \& Choy, 2020) emphasise the need for instructions that can help prospective teachers 
structure their attention (Santagata et al., 2007; Ivars et al., 2018). In our research, we assumed that those who are studying to be teachers could develop their skills to notice based on a synthesis of the knowledge provided by studies on students' mathematical thinking, specifically, knowledge provided by the learning trajectories (Clements \& Sarama, 2004; Lobato \& Walters, 2017).

A learning trajectory synthesises a gradual sequence of students' acquisition of mathematical concepts, so this would help prospective teachers interpret students' mathematical thinking (Wilson et al., 2013; Wilson et al., 2017; Ivars et al., 2018; Ivars et al., 2020). These investigations indicated the value of the learning trajectories to guide the professional noticing at the students' mathematical thinking to facilitate changes in the prospective teachers' discourse manifested by a more specific language that refers to the components of the learning trajectory.

However, we still do not understand sufficiently how prospective teachers learn to notice at students' mathematical thinking using the knowledge provided by learning trajectories. Hence, in this research, we rely on the instrumental approach (Rabardel, 2002), which allows us to analyse professional tasks from a cognitive model that addresses the activity of the prospective teacher when solving them.

The instrumental approach arises to analyse the effects of the artefacts on the students' mathematical learning (instrumentation processes) and the effects of the students' action on the artefacts (instrumentalisation processes). Generally, this approach has been used with material artefacts (calculators, computers, etc.) (Trouche, 2020); however, in our research, we have adapted it and considered a learning trajectory as a conceptual artefact (Moreno et al., 2021; Sánchez-Matamoros et al., 2018).

Therefore, this research aims to identify the instrumental genesis process characteristics in an early childhood prospective teacher when noticing a classroom situation using a learning trajectory as a conceptual artefact.

\section{THEORETICAL BACKGROUND}

The theoretical framework of this research is based on two references, an adaptation of the instrumental approach theory by Rabardel (2002) and Verillon and Rabardel (1995), cited in different studies (Trouche, 2004; Trouche, 2020; Trouche, \& Drijvers, 2014), and the professional noticing 
approach (Mason, 2002; Sherin \& van Es, 2009), from the perspective of Jacobs et al. (2010).

\section{Instrumental approach theory}

The instrumental approach contributed to understanding how complex it is to use tools (material or conceptual) in mathematical education based on the notion of scheme as a source to build knowledge.

The three key ideas of the instrumental approach, taken from cognitive ergonomics, are the distinction between artefact and instrument, instrumentalisation and instrumentation, and instrumental genesis.

The artefact is a material or a conceptual object used to perform a task. In this research, our conceptual artefact is a learning trajectory - length and its measurement - prospective teachers must learn and use to interpret teachinglearning situations. The learning trajectory 'length and its measurement' used in this research is an adaptation of Sarama and Clements' (2009), consisting of (a) a learning objective; (b) a progression of learning considering the mathematical elements that define length as magnitude (recognition of length, conservation, and transitivity) and the measurement of length (unit of measureunicity, iteration, accumulation-, universality of measurement and relationship between number and unit of measurement) (Table 1); and (c) a set of instructional tasks.

On its side, an instrument does not exist in itself. It becomes an instrument when the subjects appropriate the artefact and integrate it into their activity. An instrument is formed by an artefact or part of an artefact, mobilised in the activity and utilisation schemes.

According to the Spanish language dictionary (RAE), a scheme is an idea or concept of something that someone has and conditions his/her behaviour. For Piaget (1936), a scheme is a determined mental structure that can be transferred and generalised. Vergnaud (1996 cited in Trouche, 2003, p. 789) redefined the scheme from Piaget as the "invariant organisation of behaviour for a given class of situations," this being a dynamic functional entity. In this research, we define a scheme as a dynamic mental structure for a given class of situations that conditions the individual's response to the given situations. If false propositions form the mental structure, the individual's answers will not be adequate, and consequently, the scheme constructed will be inadequate. 


\section{Table 1}

A progression of the learning of length and its measurement magnitude (adapted from Sarama \& Clements, 2009)

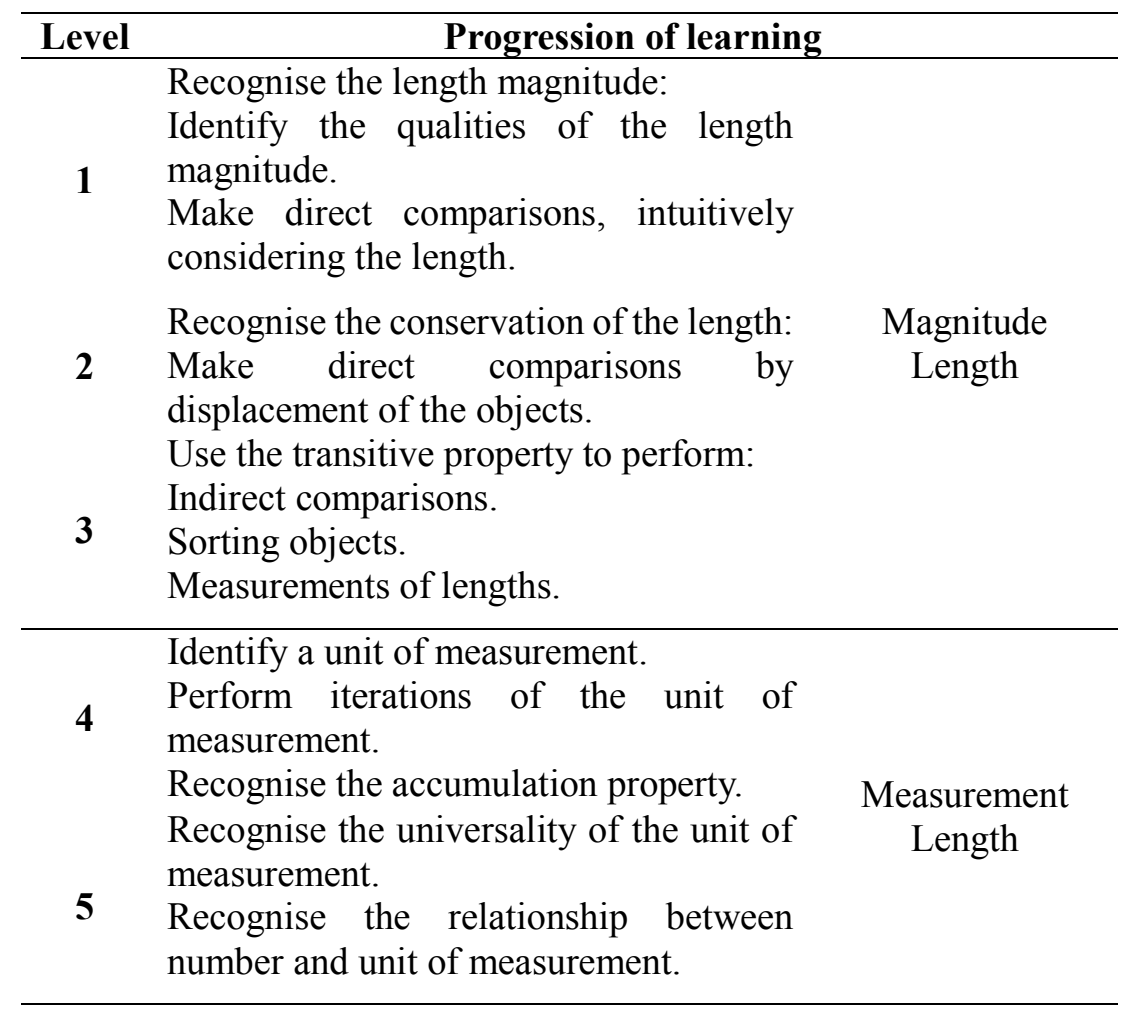

From the perspective of solving a task mediated by an artefact, Rabardel (1995, cited in Trouche, 2004) introduced the notion of utilisation scheme of an artefact as the scheme that organises the activity with an artefact associated with the performance of a given task. Likewise, the author distinguishes two types of utilisation schemes: the usage schemes (to manage the artefact) and the instrument-mediated action schemes (to carry out a specific task). The usage schemes, oriented to the management of the artefact, are elementary schemes, which means that they cannot be atomised to fulfil an identifiable sub-objective. They correspond to specific actions and activities directly related to the artefact, in our case, for example, selecting mathematical elements of the learning trajectory present in a teaching situation. 
The instrument-mediated action schemes, oriented to the performance of specific tasks, imply a restructuring of the activity directed towards the main objective of the subject. They incorporate the usage schemes. For example, in our case, a learning trajectory-mediated action scheme linked to the 'interpret' skill would be to relate the mathematical elements identified in the classroom situation to the children's level of understanding, taking into account the levels' inclusiveness and the continuity of the learning progression. Those instrument-mediated action schemes allow the subject to understand the potentialities and restrictions of the artefact itself.

Rabardel (2002) defined the third idea of cognitive ergonomics, the instrumental genesis, as the process of developing an instrument from the interaction between a subject and an artefact to face a class of situations. In the instrumental genesis process, two interrelated processes can be observed: instrumentalisation, in which the subject influences the artefact, and instrumentation, in which the artefact influences the subject's activity. Therefore, a student develops an instrument from an artefact during an instrumental genesis, combining the processes of instrumentalisation and instrumentation (Rabardel \& Bourmaud, 2003).

Instrumentalisation allows the subjects to adapt the artefact to their needs. The subjects' knowledge will guide them in selecting and using the functions they need for the action in progress; it is a process in which the subject enriches the properties of the artefact. In our research, the prospective teachers could use their knowledge to select and use the mathematical elements, the learning progression, and the set of instructional tasks that constitute the given learning trajectory (artefact). They could also enrich it if they designed new instructional tasks.

The instrumentation allows developing an activity within the limitations and potentialities of the artefact. It is important to note that the subject's use of an artefact introduces into it a cognitive activity of construction or evolution of utilisation schemes (Rabardel, 2002). In our research, the instrumentation process is evidenced when the learning trajectory becomes a conceptual instrument, for example, when the mathematical elements identified relate to the learning progression of the given trajectory to interpret the child's mathematical thinking that is manifested in the classroom situation.

\section{Professional Noticing at students' mathematical thinking}

Professional noticing has been defined as the ability to recognise important events in a classroom and give effective responses (Mason, 2002). 
Teachers face simultaneous situations and interactions in class that hinders their ability to attend to all of them. In this context, teachers should know how to effectively address classroom situations or interactions to enrich students' learning (Mason, 2002) potentially. From this perspective, Jacobs et al. (2010) conceptualise the children's perception of mathematical thinking as three interrelated skills: identifying details in children's strategies, interpreting their understanding based on the analysis of their strategies, and deciding how to respond based on children's understanding.

\section{Table 2}

Instrumental genesis process and development of the professional noticing

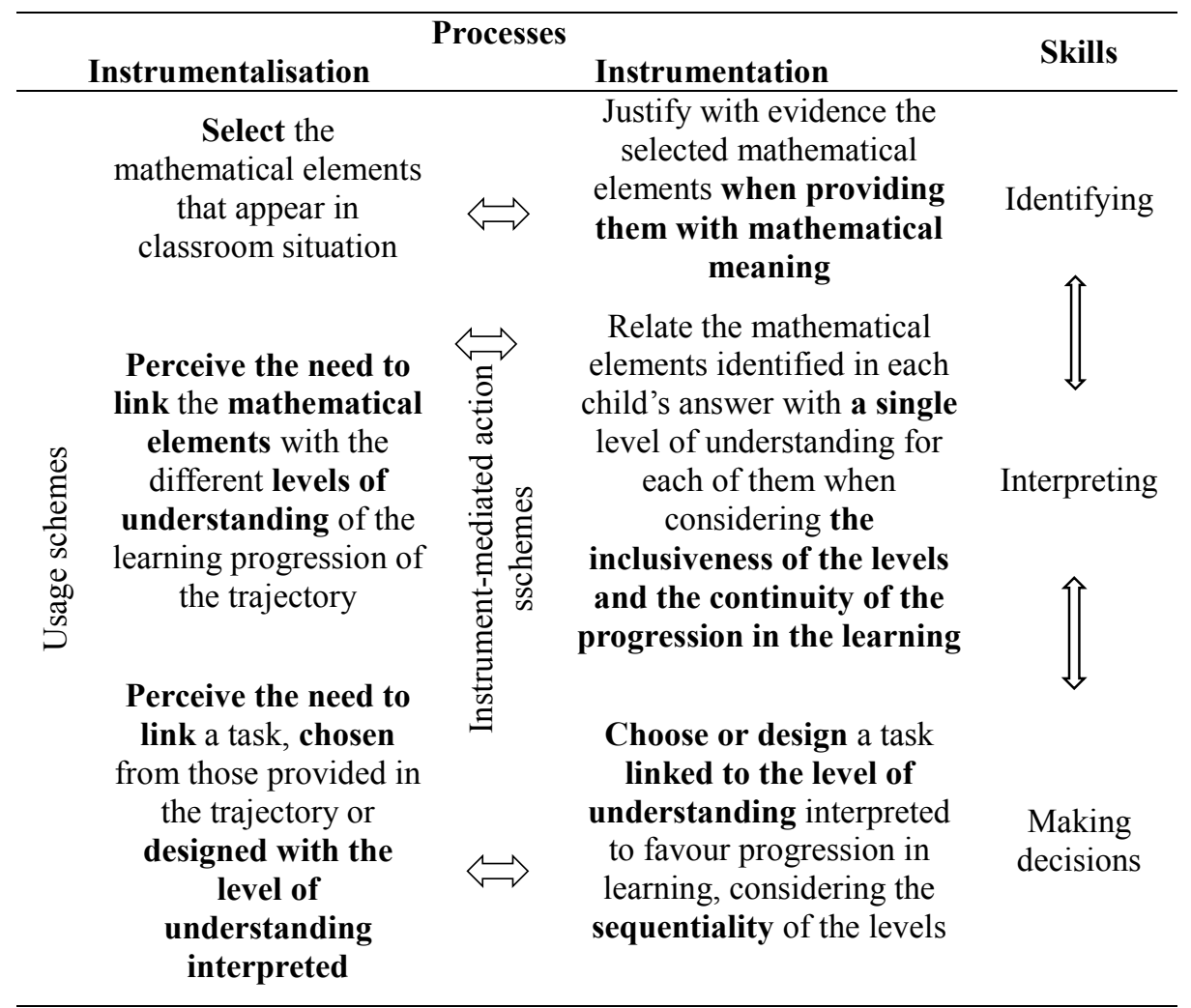

Learning to use information about learning trajectories as a conceptual instrument to notice students' mathematical thinking can be interpreted in terms 
of the processes of instrumentalisation and instrumentation that constitute the instrumental genesis. The skills that constitute the professional noticing are interrelated, and, in turn, the prospective teachers' process of acquisition and development of each depends on the construction of the utilisation schemes linked to each skill (Table 2).

Based on the research objective, we ask the following research question: What processes of instrumentalisation and instrumentation are manifest when a prospective kindergarten teacher notices professionally at a classroom situation?

\section{METHODOLOGY}

\section{Context of the case study}

The prospective kindergarten teacher in our case study was Pedro, a pseudonym we gave to preserve the participant's identity. He had concluded Practicum I (when the prospective teacher must learn about the institutional organisation of the centres) at an early childhood education centre (children aged 3 to 6 years). However, he had neither planned nor implemented any classroom programme (Practicum II and III). Before Practicum II, Pedro attended a teaching module on length and its measurement for children aged 3 to 6 years, during the school subject "Learning Geometry," offered in the sixth semester of the teaching degree in early childhood education.

The objective of the teaching module, designed ad hoc, was to develop prospective kindergarten teachers' professional noticing at mathematical thinking on the magnitude 'length and its measurement'. The module consisted of a theoretical document that included a learning trajectory of length and its measurement, three professional tasks composed of classroom situations (registers of the practice in the form of videos and/or interaction between the students and the teacher) with three questions for a structured analysis of each situation; and a teaching planning task in which they were asked to select tasks, establish consistent objectives, anticipate possible children's answers, and make decisions to favour the learning progression (Llinares, 2014, p. 37).

The module was implemented in five 100-minute sessions each. In the first session, we showed the prospective kindergarten teachers a theoretical document, and they solved the first professional task. The remaining sessions began with the large group discussion of the professional task performed in the previous session, and then they resolved the task presented below. All the professional tasks were carried out individually. In the last session, a 
professional task was proposed to assess the contents of the training programme that the prospective kindergarten teachers had acquired.

To solve the professional tasks, Pedro had the information provided in the theoretical document.

\section{Data collection instrument}

The assessment task is the data collection instrument of this research. This task is composed of a classroom situation that includes a problem proposed by a teacher and the interaction between the teacher and four children (Table 3), and (b) three professional questions.

Table 3 presents the task the teacher, Alicia, gave the children of the classroom situation of the professional task, and figure 1 shows the beads and strings used by the children to make the necklaces she proposed.

\section{Table 3}

Assignment proposed by the teacher

Alicia is a primary school teacher. She is teaching in the first cycle. It has been a week since Alicia began working with the magnitude of length and its measurement. Today, using the arts and crafts class, she proposes that children make necklaces using different materials (coloured beads and different macaroni) and strings of various sizes (A, B, and C) (Figure 2). Once she has given them the task, the children chose their strings and accessories and began making the necklaces. Alicia asked: Who has made the longest necklace?

\section{Figure 1}

Accessories of the task posed to children in the assessment professional task

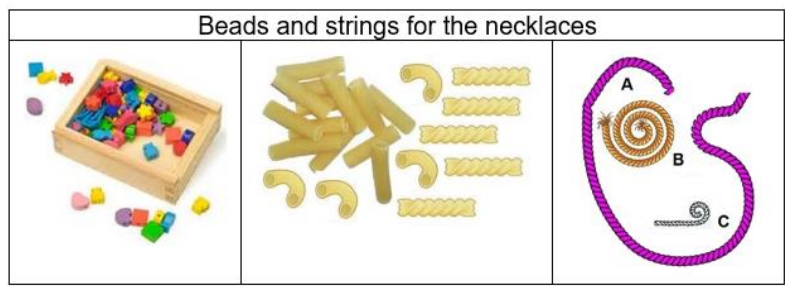


Table 4 shows the teacher's interactions with the children when solving the task she posed, which are part of the classroom situation.

The three professional questions posed to assist the prospective kindergarten teachers on the structured analysis of the classroom situation were the following:

- Question 1. Indicate the mathematical elements necessary to perform the task, from the teacher's point of view. Explain your answer.

- Question 2. In what level of understanding would you place each of the children of the dialogue? Reason your answer based on the characteristics shown and justify it using the children's interventions.

- Question 3. Assuming you are Alicia, pose a task to deepen further the understanding of the magnitude of length and its measurement for the child you consider to be at the lowest level and for the one who is at the highest level. Explain your answer.

\section{Table 4}

Teacher's interactions with the children

Mario: I made the necklace with the cane-shaped string [string C] and I used 13 macaroni [used macaroni of various types].

Almudena: Ma'm, I made a necklace with the pink string [string A] and I used 15 little stars [the little stars are very far apart].

Luis: Mine has 12 macaroni [he has used all of the same type] and I have taken the spiral-shaped string, like Mallorcan pastry [B string], but it is longer than Mario's because the string is longer.

Elena: I have also used the pink string [rope A] and I used 20 little stars [the littles stars are all together].

Almudena: So, the longest of all the necklaces is Elena's.

Based on the children's answers, Alicia asks them if they all agree.

Mario: I don't know, I don't agree with Luis because mine has more macaroni. 


\section{Justification of the data collection instrument}

With question 1 , we intend the prospective kindergarten teacher to anticipate the mathematical elements necessary to perform the task, selecting them from the learning trajectory (Table 5).

\section{Table 5}

Mathematical elements necessary to perform the task the teacher posed

\begin{tabular}{|c|c|}
\hline Magnitude elements & Measurement elements \\
\hline $\begin{array}{l}\text { - recognition of the 'length' } \\
\text { magnitude, if the children } \\
\text { realise that the strings have } \\
\text { different lengths. } \\
\text { conservation, if the } \\
\text { children assessed the } \\
\text { length of the strings } \\
\text { regardless of the way they } \\
\text { were presented. } \\
\text { - transitivity, if the children } \\
\text { indirectly compare the } \\
\text { length of three or four } \\
\text { strings used to make the } \\
\text { necklace. }\end{array}$ & $\begin{array}{l}\text { - unit of measurement-unicity, if } \\
\text { the children use a single } \\
\text { accessory to make the } \\
\text { necklace. } \\
\text { o iteration, if the children } \\
\text { repeat the chosen } \\
\text { accessory along the } \\
\text { chosen string without } \\
\text { leaving gaps. } \\
\text { accumulation, if the } \\
\text { children indicate the } \\
\text { number of accessories } \\
\text { used to make the } \\
\text { necklace. } \\
\text { relationship between the } \\
\text { number and the unit of } \\
\text { measurement if the children } \\
\text { observe that the size of the } \\
\text { accessory influences the } \\
\text { number of iterations to make } \\
\text { two necklaces with the same } \\
\text { string. }\end{array}$ \\
\hline
\end{tabular}

With question 2, we intend the prospective kindergarten teacher to identify, among the mathematical elements anticipated in the task, those that each child used, thus placing them in their corresponding level of understanding (Table 6). In other words, we intend the prospective kindergarten teacher to relate the skill of identifying the mathematical elements with interpreting the level of understanding of progression in learning. 


\section{Table 6}

Characteristics of children's understanding of the classroom situation

\begin{tabular}{|c|c|c|}
\hline Children & Characteristics of understanding & Level \\
\hline Mario & $\begin{array}{l}\text { There is evidence that } \\
\text { - He DOES NOT understand the conservation of the } \\
\text { length (element of magnitude). Mario considers that his } \\
\text { necklace is longer than Luis's and does not notice that } \\
\text { string B is longer than string C but with a different } \\
\text { shape. } \\
\text { - He DOES NOT consider the unicity of the unit of } \\
\text { measurement (measurement element) } \\
\text { Mario uses macaroni of different sizes. }\end{array}$ & \\
\hline Almudena & $\begin{array}{l}\text { There is evidence that } \\
\text { - She DOES NOT understand the conservation of the } \\
\text { length (element of magnitude). } \\
\text { Almudena indicates that Elena's necklace is the longest, } \\
\text { while both have used the same string. } \\
\text { - She DOES consider the unicity of the unit of } \\
\text { measurement (measurement element) } \\
\text { She uses only little stars to make her necklace } \\
\text { - She DOES NOT consider the iteration of the unit of } \\
\text { measurement (measurement element) } \\
\text { She leaves gaps between the little stars used to make } \\
\text { the necklace. }\end{array}$ & 1 \\
\hline Luis & $\begin{array}{l}\text { There is evidence that } \\
\text { - He DOES understand the conservation of the length } \\
\text { (element of magnitude). } \\
\text { Luis compares Mario's string (cane-shaped) and his } \\
\text { (spiral-shaped) and indicates that Mario's necklace is } \\
\text { longer because his string is longer } \\
\text { - He DOES consider the unicity of the unit of } \\
\text { measurement (measurement element) } \\
\text { He uses a single type of macaroni } \\
\text { - Hee DOES consider iteration and accumulation } \\
\text { (measurement elements) } \\
\text { He does not leave gaps between the macaroni and } \\
\text { indicates the amount of them he used }\end{array}$ & 4 \\
\hline Elena & $\begin{array}{l}\text { There is evidence that } \\
\text { - She DOES consider the unicity of the unit of } \\
\text { measurement (measurement element) }\end{array}$ & \\
\hline
\end{tabular}


Elena uses only little stars of the same type

- She DOES consider iteration and accumulation (measurement elements)

She does not leave gaps between the little stars and indicates that her necklace has 20 little stars.

With question 3, we intend that once each child is placed at the corresponding level of understanding, the prospective kindergarten teacher designs a new task or choose one of the proposals in the learning trajectory and establish the corresponding objective so that the child progresses in his/her learning. In other words, we intend the prospective kindergarten teacher to relate the three skills of identifying-interpreting-making decisions.

\section{Case Study Analysis}

The answers to the three questions posed in the assessment professional task (data) have been analysed considering the processes of instrumentalisation (usage schemes) and instrumentation (instrument-mediated or instrumented action schemes) of the learning trajectory through the evidence manifested by Pedro (the prospective kindergarten teacher) in his answers to the professional task mentioned (Table 7).

The qualitative analysis, we carried out and triangulated, allowed us to see how Pedro could transform the conceptual artefact, the learning trajectory 'length and its measurement', into a conceptual instrument.

For the analysis, the information was organised in tables as follows: Pedro's answers appear in the first column, and in the following columns, the evidence that allows inferring each of the utilisation schemes Pedro built is selected from the answers, indicating whether they are adequate and why, and to what skill they are linked. For this analysis, we took Table 7 as a reference. An example of this analysis process for identifying and interpreting skills is shown in Table 8. 


\section{Table 7}

Instrumental Genesis Processes in the classroom situation raised

\begin{tabular}{|c|c|c|}
\hline \multirow{2}{*}{$\begin{array}{c}\text { Questions } \\
\text { of the } \\
\text { task }\end{array}$} & \multicolumn{2}{|c|}{ Processes } \\
\hline & Instrumentalisation & Instrumentation \\
\hline $\begin{array}{c}\text { Question } \\
1\end{array}$ & $\begin{array}{l}\text { Does Pedro anticipate the } \\
\text { mathematical elements } \\
\text { that would allow solving } \\
\text { the task proposed by the } \\
\text { teacher in the classroom } \\
\text { situation by selecting } \\
\text { them from the learning } \\
\text { trajectory? }\end{array}$ & $\begin{array}{l}\text { Does Pedro justify the } \\
\text { selection of each of those } \\
\text { anticipated mathematical } \\
\text { elements, linking them to } \\
\text { the task proposed by the } \\
\text { teacher in the classroom } \\
\text { situation? }\end{array}$ \\
\hline & $\begin{array}{l}\text { Does Pedro select, from } \\
\text { among all the anticipated } \\
\text { mathematical elements, } \\
\text { those that appear in the } \\
\text { classroom situation in }\end{array}$ & $\begin{array}{l}\text { Does Pedro justify with } \\
\text { evidence the selected } \\
\text { mathematical elements by } \\
\text { providing them with } \\
\text { mathematical meaning? }\end{array}$ \\
\hline & dialogues? & Does Pedro relate the \\
\hline $\begin{array}{c}\text { Question } \\
2\end{array}$ & $\begin{array}{l}\text { Does Pedro perceive the } \\
\text { need to link the } \\
\text { mathematical elements, } \\
\text { both of magnitude and of } \\
\text { measure, with the different } \\
\text { levels of understanding } \\
\text { manifested in the } \\
\text { progression of the learning } \\
\text { trajectory? }\end{array}$ & $\begin{array}{l}\text { mathematical elements } \\
\text { identified in each child's } \\
\text { answer with a single level } \\
\text { of understanding for each } \\
\text { of them when considering } \\
\text { the inclusiveness of the } \\
\text { levels and the continuity } \\
\text { of the progression in the } \\
\text { learning? }\end{array}$ \\
\hline $\begin{array}{c}\text { Question } \\
3\end{array}$ & $\begin{array}{l}\text { Does Pedro choose a task } \\
\text { from among the tasks of } \\
\text { the learning trajectory, or } \\
\text { he designs a new one, } \\
\text { perceiving, in any case, the } \\
\text { need to link the task with } \\
\text { the level of } \\
\text { understanding } \\
\text { interpreted? }\end{array}$ & $\begin{array}{l}\text { Does Pedro choose or } \\
\text { design a task to favour } \\
\text { progression in learning } \\
\text { considering the } \\
\text { sequentiality of the levels } \\
\text { in relation to the level of } \\
\text { understanding } \\
\text { interpreted? }\end{array}$ \\
\hline
\end{tabular}




\section{Table 8}

Example of the qualitative analysis process carried out

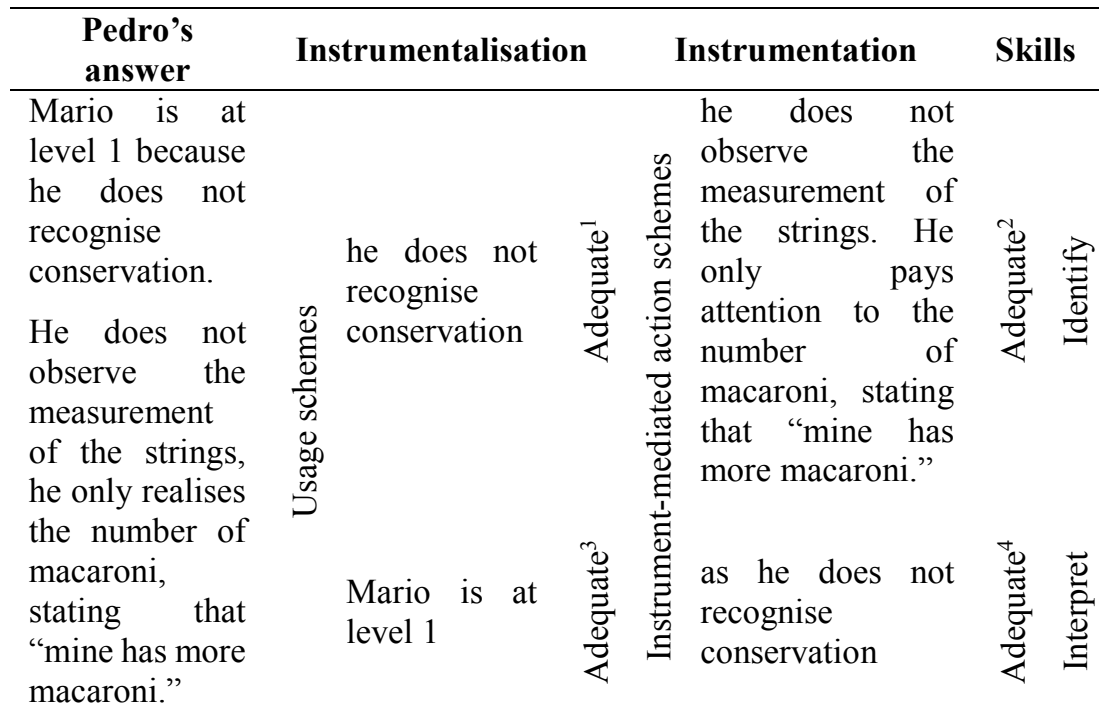

1. Select the conservation element involved in the classroom situation from among the anticipated elements.

2. Justify with evidence the conservation element by providing it with its mathematical meaning.

3. Perceive and link the conservation element with the level of understanding of the progression in the learning.

4. Relate not having the conservation element with level 1 understanding

\section{RESULTS}

Our results have been organised in three sections, in which we describe each of the instrumentalisation and instrumentation processes Pedro built linked to 'identifying', 'interpreting' and 'making decisions' skills. 


\section{Process of instrumentalisation and instrumentation in the 'identify' skill}

Pedro manifests instrumentalisation processes in the usage schemes to solve question 1, selecting from the learning trajectory the mathematical elements of magnitude and measurement that he thinks the teacher considers necessary for the young children solve the task, as evidenced in his answers. In addition, we have evidence of the instrumentation process since Pedro's justification of each of the elements selected shows how the children would use them to solve the task posed in the classroom situation. Pedro justifies each of the elements chosen. For example, regarding the accumulation element, he indicates: "accumulation (knowing how to count the iterations and the final result equals the total number of iterations performed)."

Pedro's answer:

The mathematical elements necessary to carry out the activity would be all those of the learning trajectory.

\begin{tabular}{|l|l|}
\hline $\begin{array}{l}\text { Magnitude elements } \\
\text { Recognition of the } \\
\text { length magnitude }\end{array}$ & $\begin{array}{l}\text { Measurement elements } \\
\text { - } \begin{array}{l}\text { Unit of measurement } \\
\text { Conservation }\end{array} \\
\begin{array}{l}\text { equality of lengths in } \\
\text { different cases using } \\
\text { the same material) }\end{array}\end{array} \begin{array}{l}\begin{array}{l}\text { Iteration of the unit of } \\
\text { measurement (perform the } \\
\text { iterations correctly, without } \\
\text { jumps or overlaps) }\end{array} \\
\begin{array}{l}\text { Transitivity (for } \\
\text { comparison, reference } \\
\text { will be made) }\end{array}\end{array} \mid \begin{array}{l}\text { Accumulation (knowing how to } \\
\text { count the iterations and the } \\
\text { final result equals the total } \\
\text { number of iterations } \\
\text { performed) } \\
\text { Recognition of the universality } \\
\text { of the unit of measurement } \\
\text { (know that the same instrument } \\
\text { must be used to measure in all } \\
\text { cases) }\end{array}$ \\
$\begin{array}{l}\text { Relate the word number with the } \\
\text { unit of measurement (know that by } \\
\text { using larger accessories, he will } \\
\text { need less) }\end{array}$
\end{tabular}


In question 2, Pedro has carried out an instrumentalisation process from the constructed usage scheme by selecting from among all the anticipated mathematical elements the elements of magnitude: conservation, transitivity, and those of measurement: unit of measurement, unicity, iteration and accumulation, focusing on the children's dialogues. Likewise, Pedro has carried out an instrumentation process by constructing appropriate instrumentmediated action schemes -by justifying with evidence the measurement elements selected: unit of measure, unicity, iteration and accumulation, demonstrating that he has provided his mathematical meaning to said elements.

However, the instrument-mediated action scheme Pedro built for the element transitivity is inadequate. Pedro justifies having selected this element based on the evidence "Elena's is the longest," from Almudena's answer, without taking into account that, to make this comparison, this girl has set herself in the number of accessories used by each child and not in the lengths of the strings. Thus, Pedro has not linked the evidence with the mathematical meaning of the element. Regarding the conservation element, Pedro has built the instrument-mediated action scheme evidencing it in Mario and Luis, and not in Almudena, by not expliciting in his response that she does not recognise the element at stake.

Pedro's answer:

Mario [...] does not recognise conservation. He does not observe the measurement of the strings, he only pays attention to the number of macaroni, stating that "mine has more macaroni." Likewise, he does not perform transitivity because he does not recognise the measurement of the strings, he cannot compare them, and he does not use a single unit of measurement that, as he says in the text, uses macaroni of different types.

Almudena [...] perceives the unicity of the unit of measurement, "she always uses little stars," she does not have the concept of iteration, "she still does not master the iteration correctly" when performing, "she skips, which causes the length to increase," and [...] she masters the transitive property when she says that "Elena's is the longest."

Luis [...] iterates correctly, without skipping or overlapping. And he recognises conservation because he knows that the strings have different measures, and his necklace is longer than Mario's, "it is longer than Mario's, even though the accessories are different." 
Elena $[\ldots]$ performs the iterations correctly and always uses the same unit of measurement [unicity] "the little stars". She recognises the unit of measurement and the iterations.

Therefore, Pedro has carried out both processes of instrumental genesis in the identification of the measurement elements: unit of measure, unicity, iteration and accumulation, having built different usage schemes, correctly linking the selected measurement elements to the corresponding evidence extracted from each child's speech, stating that they have given them their mathematical meaning. However, he has not completed both instrumentation processes for some elements of magnitude successfully. In this way, we would say that Pedro has acquired the skill of 'identifying in relation to the measurement of the length', but he shows difficulties regarding some elements of magnitude, which he recognises only in some contexts.

\section{Process of instrumentalisation and instrumentation in the interpret skill}

Pedro manifests processes of instrumentalisation in the usage schemes built in his answer to question 2 by linking each of the mathematical elements, both of magnitude and of measure, with the different levels of understanding manifested in the progression of the learning trajectory. Likewise, Pedro manifests instrumentation processes in the instrument-mediated action schemes when he relates the mathematical elements identified with a single level of understanding of the children when considering the inclusiveness and the continuity of the learning progression levels.

For example, Pedro is aware that although Mario shows he can perform iterations and recognise the accumulation correctly (mathematical elements linked to level 4), he interprets a lower level of understanding (level 1) for Mario, as he does not recognise conservation. Pedro has considered the inclusiveness of the levels and their continuity to interpret the level of understanding of Mario and the rest of the children of the classroom situation, as evidenced in his answer. However, the level of understanding interpreted for Almudena (transition from level 3 to 4) would not correspond to the girl's level of understanding, since Pedro did not attribute a mathematical meaning to the the transitivity element, and did not show evidence that the conservation element was implicit in Almudena's answer. 


\section{Pedro's answer:}

Mario is at level 1 because he does not recognise conservation, [see justification in the previous section].

Almudena is in the transition from level 3 to 4 because she perceives the unicity of the unit of measurement $[\ldots]$, she does not have the concept of iteration [...], and we can see that she reached level 3 by mastering the transitive property [...].

Luis is at level 4 because he has already acquired the iteration [...]. And he recognises conservation because $[\ldots]$.

Elena is at level $4[\ldots]$. She recognises the unit of measurement [unicity] and the iterations.

Therefore, Pedro has carried out both processes of instrumental genesis to interpret the levels of understanding of Mario, Almudena, Luis, and Elena when considering the inclusiveness of the levels of understanding and the continuity of the learning progression. Consequently, he has acquired the skill of interpreting for the concept of magnitude length and its measurement and has interrelated the skills of identifying and interpreting. However, in Almudena's case, Pedro has not identified the conservation element, which has prevented him from correctly interpreting her level of understanding.

\section{Process of instrumentalisation and instrumentation in the decision- making skill}

Pedro manifests processes of instrumentalisation in the usage schemes built by answering question 3, by linking the tasks designed, based on the type of tasks provided in the trajectory, with the level of understanding interpreted for Mario (lower level) and for Luis and Elena (upper level). Likewise, Pedro manifests instrumentation processes in the instrument-mediated action schemes built when answering question 3 , when linking the tasks designed to the levels of understanding interpreted for the lower and upper levels, considering their sequentiality.

Pedro designs a task for Mario to recognise conservation and use the transitive property to make indirect comparisons and thus progress from level 1 to 2 and from level 2 to 3 . For children at a higher level, he designs a task so that they recognise the relationship between numbers and units of measurement, which will allow them to progress from level 4 of understanding to level 5 . 
Pedro's answer:

For Mario, the goal would be to recognise conservation and transitivity.

Task that I proposed: make direct and indirect comparisons with strings placed in different shapes and different positions.

For the more advanced, the aim is to recognise the relationship between the number and the unit of measurement.

The task: I would present them necklaces made with the same strings but different beads so that, when they counted them, they would observe that the measurement is maintained [but not the number of iterations]; I would also show them necklaces of different lengths. By the way, the concept of accumulation would be deepened, as the measurement of the necklaces is always constant, when appropriate

Therefore, Pedro has carried out both processes of instrumental genesis to make decisions for children at lower and higher level of understanding to progress in their learning when considering the sequentiality of the levels of understanding. Consequently, he has acquired the skill 'making decisions' of the competence 'professional noticing' children's mathematical thinking, and has interrelated the three skills.

Pedro has been able to transform the conceptual artefact, the learning trajectory of length and its measurement, into a conceptual instrument. Pedro has realised the idea of progression of learning in the sense that levels of understanding are increasingly sophisticated and that a specific level of understanding cannot be reached without the acquisition of all the previous levels (inclusiveness, sequentiality of levels). In addition, he perceives the learning progression as a continuous process.

\section{CONCLUSIONS}

This research aims to identify characteristics of the instrumental genesis process in a prospective kindergarten teacher when noticing a classroom situation using a learning trajectory as a conceptual artefact.

The results indicate that, in general terms, Pedro transformed the conceptual artefact into an instrument, through coordinating instrumentalisation and instrumentation processes of the instrumental genesis, by having built simultaneously the following usage schemes and instrumentmediated action schemes, respectively: to select, giving meaning to the 
mathematical elements of the trajectory; to link them with the levels of understanding, assuming their inclusiveness and the continuity of the learning progression; and to choose/design tasks linked to these levels of understanding, assuming their sequentiality, to notice the mathematical thinking of the children in the classroom situation posed. This fact shows how Pedro has appropriated the knowledge provided by the learning trajectory to notice classroom situations professionally (Moreno et al., 2021).

The instrumental genesis mediated by a learning trajectory allows us to understand how the utilisation schemes have been built to transform the learning trajectory into a conceptual instrument and, therefore, to understand when this construction of schemes has been adequate or not. Providing mathematical meaning to the elements allows to adequately construct the usage schemes linked to the skill 'identify'. Considering the inclusiveness of the levels of understanding and the continuity of the learning progression allows us to adequately construct the utilisation schemes linked to the 'interpret' skill. Finally, considering the sequentiality of the levels of understanding allows to adequately construct the utilisation schemes linked to 'making decisions' skill. The construction of those schemes linked to each of the skills can be done alone, although developing the teaching competence that allows the learning progression of all students requires giving meaning to all the components of the learning trajectory (mathematical elements, learning progression, and tasks) and interrelate them.

The theory of instrumental genesis used in the analysis of Pedro's case has allowed us to realise how this future teacher has constructed the utilisation schemes linked to the three skills of the professional noticing. Thus, Pedro has adequately constructed the utilisation schemes linked to 'interpreting' and 'making decisions' skills but not those linked to the 'identifying' skill, since he has not given a mathematical meaning to the transitivity element, which was shown by his answer about Almudena. Moreover, Pedro seems to have had difficulties with the conservation element since the instrument-mediated action scheme built for Almudena has not been generalised. Therefore, although he interrelated the three skills, by doing so based on some inappropriate usage schemes, his professional noticing in a real classroom situation related to the mathematical elements transitivity and conservation will not allow him to favour all childrens' learning progression. This fact corroborates the results of previous research, in which mathematics knowledge is considered a necessary condition to develop the professional noticing (Fernández et al., 2013; Son, 2013). 
Another relevant aspect that we report in this research is the specificity of the language the prospective teacher uses regarding the learning trajectory that has allowed him to give mathematical meaning to the classroom situation provided. This specificity of the prospective teacher's discourse is supported by research by Ivars et al. (2018) and Ivars et al. (2020).

On the other hand, from the perspective of the prospective teachers' educator, the instrumental genesis is a powerful conceptual framework that allows discriminating between the processes of instrumental genesis that the prospective teacher has properly constructed and those that he has not, regarding the skills of the professional noticing. This potential of the instrumental genesis could allow the teachers' educator to discriminate between the utilisation schemes linked to some of the skills that the prospective teacher has adequately built and, among those, linked to other skills that he has not, and to adopt the necessary instructional decisions so that he constructs them adequately. In Pedro's case, the educator should adopt decisions that affect the mathematical meaning of the transitivity element and facilitate different contexts that entail the conservation element. These decisions should provide several everyday situations related to these elements to turn them into teachinglearning situations, as other studies support (Gasteiger \& Benz, 2018; Gasteiger et al., 2020).

Based on the results of this research, we can suggest how teacher educators can design teaching modules to develop the teaching competence mediated by a learning trajectory in prospective teachers' training. The teacher educator can design professional tasks that initially affect each of the skills independently so that the prospective teachers can construct the usage schemes linked to each of the skills. Once those usage schemes are built, they can design tasks whose resolutions require the prospective teachers to coordinate the schemes needed to relate two of the three skills and terminate other tasks that require them to coordinate utilisation schemes needed to interrelate the three skills. In this way, the teacher educator could discriminate between the utilisation schemes that are properly constructed and those that are not, and between their coordination or not, which would allow him/her to make decisions to develop the teaching competence. 


\section{ACKNOWLEDGEMENTS}

This research was funded by the national Spanish Project: EDU201787411-R and PID2020-116514GB-I00 - "Ministerio de Economía and Competitividad, Gobierno de España”.

\section{AUTHORSHIP CONTRIBUTIONS STATEMENTS}

All authors have contributed equally to the development of this study in all its parts.

\section{REFERENCES}

Amador, J. (2020). Noticing as a tool to analyze mathematics instruction and learning. In S. Llinares, \& O. Chapman (eds.), International Handbook of Mathematics Teacher Education. Volume 2: Tools and Processes in Mathematics Teacher Education. (p. 310-336). Brill Sense.

Bartell, T.G., Webel, C., Bowen, B., \& Dyson, N. (2013). Prospective teacher learning: recognizing evidence of conceptual understanding. Journal of Mathematics Teacher Education, 16, 57-79.

Clements, D.H., \& Sarama, J. (2004). Learning trajectories in mathematics education. Mathematical thinking and Learning, 6, 81-89.

Empson, S., \& Junk, D. (2004). Teachers "knowledge of children" mathematics after implementing a student-centered curriculum. Journal of Mathematics Teacher Education, 7(2), 121-144.

Fernández, C., \& Choy, B.H. (2020). Theoretical Lenses to develop Mathematics Teacher Noticing. In S. Llinares, \& O. Chapman (eds.), International Handbook of Mathematics Teacher Education. Volume 2: Tools and Processes in Mathematics Teacher Education, (p. 337-360). Brill Sense.

Fernández, C., Llinares, S., \& Valls, J. (2013). Primary school teacher's noticing of students' mathematical thinking in problem solving. The Mathematics Enthusiast, 10(1), 441-468.

Gasteiger, H., \& Benz, C. (2018). Enhancing and analyzing kindergarten teachers' professional knowledge for early mathematics education. 
Journal of Mathematical Behavior, 51, 109-117. https://doi.org/10.1016/j.jmathb.2018.01.002.

Gasteiger, H., Bruns, J., Benz, C., Brunner, E., \& Sprenger, P. (2020). Mathematical pedagogical content knowledge of early childhood teachers: a standardized situation-related measurement approach. ZDM Mathematics Education 52, 193-205. https://doi.org/10.1007/s11858019-01103-2.

Ivars, P., Fernández, C., Llinares, S., \& Choy, B.H. (2018). Enhancing Noticing: Using a Hypothetical Trajectory to Improve Pre-service Primary Teachers' Professional Discourse. Eurasia Journal of Mathematics, Science and Technology Education, 14(11), em1599. https://doi.org/10.29333/ejmste/93421

Ivars, P., Fernández, C., \& Llinares, S. (2020). A Learning Trajectory as a Scaffold for Pre-service Teachers' Noticing of Students' Mathematical Understanding. International Journal of Science and Mathematics Education, 18, 529-548.

Jacobs, V.R., Lamb, L.C., \& Philipp, R. (2010). Professional noticing of children's mathematical thinking. Journal for Research in Mathematics Education, 41(2), 169-202.

Krupa, E. E., Huey, M., Lesseig, K., Casey, S., \& Monson, D. (2017). Investigating secondary preservice teacher noticing of students' mathematical thinking. In E. O. Schack et al. (Eds.). Teacher Noticing: Bridging and Broadening Perspectives, Contexts, and Frameworks (pp. 49-71). Springer.

Lee, J.E. (2017). Preschool Teachers' Pedagogical Content Knowledge in Mathematics. International Journal of Early Childhood, 49, 229-243. https://doi.org/10.1007/s13158-017-0189-1.

Llinares, S. (2014). Experimentos de enseñanza e investigación. Una dualidad en la práctica del formador de profesores de matemáticas. Educación matemática, 25 años. (p. 31-51).

Llinares, S. (2012). Construcción de conocimiento y desarrollo de una Mirada profesional para la práctica de enseñar matemáticas en entornos en línea. AIEM. Avances de Investigación en Educación Matemática, 2, 53-70. 
Lobato, J., \& Walters, C.D. (2017). A taxonomy of approaches to learning trajectories and progressions. In J. Cai (Ed.). Compendium for Research in Mathematics Education, 74-101.

Mason, J. (2002). Researching your own practice. The discipline of noticing. Routledge.

Moreno, M., Sánchez-Matamoros, G., Callejo, M. L., Pérez-Tyteca, P., \& Llinares, S. (2021). How prospective kindergarten teachers develop their noticing skills: the instrumentation of a learning trajectory. ZDMMathematics Education, 53(1), 57-72.

Parks, A. M., \& Wager, A. A. (2015). What knowledge is shaping teacher preparation in early childhood mathematics? Journal of Early Childhood Teacher Education, 36 (2), 124-141. https://dx.doi.org/10.1080/10901027.2015.1030520.

Rabardel, P. (2002). People and technology - a cognitive approach to contemporary instruments. Université Paris 8.

Rabardel, P., \& Bourmaud, G. (2003). From computer to instrument system: a developmental perspective. Interacting with computers, 15(5), 665691.

Sánchez-Matamoros, G., Moreno, M., Perez-Tyteca, P., \& Callejo, M.L. (2018). Trayectorias de aprendizaje de la longitud y su medida como instrumento conceptual usado por futuros maestros de educación infantil. RELIME - Revista Latinoamericana de Investigación en Matemática Educativa, 21(2), 203-228.

Santagata, R., Zannoni, C., \& Stigler, J. W. (2007). The role of lesson analysis in pre-service teacher education: An empirical investigation of teacher learning from a virtual video-based field experience. Journal of Mathematics Teacher Education, 10(2), 123-140.

Sarama J., \& Clements D. (2009). Early Childhood Mathematics Education Research. Learning Trajectories for Young Children. Routledge.

Sherin, M.G., \& Van Es, E. A. (2009). Effects of video club participation on teachers' professional vision. Journal of teacher education, 60(1), 2037.

Son, J. (2013). How preservice teachers interpret and respond to student errors: ratio and proportion in similar rectangles. Educational Studies in Mathematics, 84, 49-70. 
Stockero, S.L. (2014). Transitions in prospective mathematics teacher noticing. In J. L. Lo et al. (eds.), Research Trends in Mathematics Teacher Education. (pp. 239- 259). Springer.

Trouche, L. (2003). From artifact to instrument: mathematics teaching mediated by symbolic calculators. Interacting with Computers, 15(6), 783-800.

Trouche, L. (2004). Managing the complexity of human/machine interactions in computerized learning environments: Guiding students' command process through instrumental orchestrations. International Journal of Computers for mathematical learning, 9(3), 281-307.

Trouche, L. (2020). Instrumentalization in mathematics education. Encyclopedia of Mathematics Education. (p. 404-412). Springer,

Trouche, L., \& Drijvers, P. (2014). Webbing and orchestration. Two interrelated views on digital tools in mathematics education. Teaching Mathematics and Its Applications: International Journal of the IMA, 33(3), 193-209.

Vergnaud, G. (1996). The theory of conceptual fields. Theories of mathematical learning. (p. 219-239)

Wilson, P.H., Mojica, G., \& Confrey, J. (2013). Learning trajectories in teacher education: Supporting teachers' understanding of students' mathematical thinking. Journal of Mathematical Behavior, 32, 103121.

Wilson, P.H., Sztajn, P., Edgington, C., Webb, J., \& Myers, M. (2017). Changes in Teachers' Discourse about students in a professional Development on Learning Trajectories. American Educational Research Journal, 54(3), 568-604. 